\title{
Guiding students in Singapore to investigate historical controversy using a disciplinary approach
}

\author{
Mark Baildon*, Suhaimi Afandi, Sandra Bott and Chelva Rajah - National \\ Institute of Education, Nanyang Technological University, Singapore
}

\begin{abstract}
In this article, we make the case for teaching historical controversy on disciplinary and educational grounds. We outline an approach for teaching controversial history topics that engages students with authentic historical problems, such as historical controversies or actual debates taken up by historians, and allows students to participate in history as an interpretative enterprise. The disciplinary approach we suggest can also help teachers practically manage the challenges of teaching contentious topics by drawing on the disciplinary methods and standards used in history. Teaching controversial topics is challenging in many contexts, and in this article we highlight some of the challenges teachers in Singapore face when teaching controversial topics in history classrooms. We also draw on research that examines the conceptions Singaporean students hold about history and the nature of accounts in history. We argue that teaching historical controversy can help students develop their conceptual understanding of historical accounts, understand the nature of history as a discipline, and build their historical knowledge. We conclude by arguing that in a time of widespread access to multiple and often competing accounts about past and present in social media, a discipline-based history education is more important than ever.
\end{abstract}

Keywords: Singapore; national identity; historical controversy; historical reasoning; conceptual understanding; disciplinary practice; accounts

\section{Introduction}

The teaching of controversial issues in history classrooms is often the focus of intense academic, public and political debate (Baildon et al., 2014; Foster, 2014). This article outlines a disciplinary approach to guide teachers and students in their investigations of controversial history topics in Singapore, where the national context often presents challenges to the teaching of contentious topics. This is primarily because of the importance history education plays in developing national identity, collective memory, and beliefs about the legitimacy of the current political, economic and social order (Foster and Crawford, 2006). This is not unique to Singapore - history education is often subordinated to national imperatives (Afandi and Baildon, 2010) and 'divorced from the practices of academic history' (Foster, 2014: 21). As Loh et al. (2014: 4) have argued, 'the effort to promulgate collective memory and create a national identity often trumps teaching historical thinking as a disciplinary or critical practice'.

In this article, we make the case for teaching historical controversy on disciplinary and educational grounds, and highlight some of the challenges teachers in Singapore 
face when teaching controversial topics in history classrooms. We also draw on research that examines the conceptions students hold about history and the nature of accounts in history. We then outline a disciplinary approach to teaching historical controversy that aims to help students develop their conceptual understanding of historical accounts, understand the nature of history as a discipline, and build their historical knowledge.

A disciplinary approach can also help teachers practically manage the challenges of teaching contentious topics. We conclude by arguing that engaging students with authentic historical problems, such as historical controversies or actual debates taken up by historians, and allowing students to participate in history as an interpretative enterprise, supports student engagement, conceptual growth and student learning. In a time of widespread access to multiple and often competing accounts about past and present in social media, a discipline-based history education is more important than ever.

\section{The value of disciplinary history}

As a disciplinary practice, history is a complex, interpretative field of study, based on systematic and rigorous methods to make meaning of the past. It includes working with a wide variety of primary sources, being able to interrogate these documents, and organizing knowledge around key historical concepts such as evidence, causation, change and continuity to explain the past. It requires understanding that historical explanations, accounts and narratives are always authored, plural, and open to contestation and revision in light of new questions, new evidence or more compelling arguments. It is through the application of disciplinary standards and open debate that different explanations and accounts can be critically assessed, revised and validated.

Across different national contexts, history education scholars have made a strong case, since the 1960s, for helping teachers and students understand the disciplinary basis of history (for example, Baildon and Afandi, 2014; Chapman, 2011; Körber, 2015; Lee, 2011; Nordgren, 2016). For example, Lee (1991: 48-9) argues that:

[It is] absurd ... to say that schoolchildren know any history if they have no understanding of how historical knowledge is attained, its relationship to evidence, and the way in which historians arbitrate between competing or contradictory claims. The ability to recall accounts without any understanding of the problems involved in constructing them or the criteria involved in evaluating them has nothing historical about it. Without an understanding of what makes an account historical, there is nothing to distinguish such an ability from the ability to recite sagas, legends, myths or poems.

Core to historical reasoning is the ability to arbitrate between multiple, competing and contradictory claims, and their evidentiary validity. Engaging students in disciplinary practice, then, means helping students understand how knowledge about the past is 'constructed, adjudicated and arbitrated' (Afandi and Baildon, 2015: 36).

Historical controversies can be focal points to help students understand that historians make arguments or claims about the past (through different explanations, accounts and narratives), and that these often lead to debates and controversies, not only within the community of historians but also in public life. Treating history education as disciplinary practice would require teachers and students to critically assess claims made about the past, the reasons provided, and the evidence used to support various 
claims. Since controversies involve dispute, contention and competing or contradictory claims, they become prime opportunities to develop essential historical reasoning skills, if handled properly (Baildon and Afandi, 2014).

\section{Challenges to history education in Singapore}

There are three significant challenges faced by history educators in Singapore:

(1) emphasis on a singular narrative for purposes of national cohesion

(2) national high-stakes examinations

(3) out-of-bounds (OB) markers that inhibit addressing controversial issues.

Singapore has a highly centralized education system and history education has been viewed as vital for nation-building, to develop a common national identity necessary to unite a highly diverse population (Gopinathan, 1999). History education in Singapore has emphasized the transmission of the 'Singapore story' by focusing on key events, such as the founding of Singapore by Sir Stamford Raffles and colonial rule, Japanese occupation during World War Two, merger with Malaysia (1963), separation and independence (1965), and remarkable social and economic development due to strong political leadership. The themes of vulnerability and survival are central to the historical narrative presented in the school curriculum and textbooks (Afandi and Baildon, 2010). According to then Deputy Prime Minister Lee Hsien Loong (Lee, 1997), the Singapore story is 'objective' and 'based on historical facts'.

However, as Baildon and Afandi (2017) point out, the focus on an unproblematic history means students fail to appreciate the ways in which certain decisions or policies were contested or may have posed particular dilemmas to people in the past. Similar to other history curricula designed to promote national agendas, Singapore's history curriculum tends to leave out contentious episodes (such as Operation Coldstore, see below) or downplay others (such as the use of the Internal Security Act to detain citizens).

A second, related, challenge is the examination-driven focus in history classrooms. The result is an almost universal perception of history as a subject that is 'uncritical' and 'mundane' (Afandi and Baildon, 2010). Across different subjects, including history, national examinations 'remain purveyors of a nation-wide obsession with excelling in examinations', despite numerous reforms over the past thirty years (Deng and Gopinathan, 2016: 456). This has resulted in the persistence in Singapore of a pedagogic culture of teacher-centred classroom practice that emphasizes, with few exceptions, the transmission of knowledge and procedures for exam success, rather than conceptual understanding, classroom discussion and knowledge building (Deng and Gopinathan, 2016; Hogan et al., 2013).

Finally, 'out-of-bounds' (OB) markers operate in Singapore to define the acceptable boundaries of public discourse, and serve to inhibit discussion of controversial issues in classrooms (Baildon and Sim, 2009). They produce an environment of self-censure, cautiousness and uncertainty about whether or not teachers may get into 'trouble' for raising controversial topics in Singapore's history. Because history education in Singapore aims to develop national identity and collective memory, historical accounts that challenge the official narrative of the Singapore story may be viewed as out of bounds for teachers. The case of Operation Coldstore, which we use to outline our approach below, is an example of a contentious topic that some teachers may consider out of bounds, although professional historians continue to 
debate whether it constituted a genuine security threat or was politically motivated to eliminate opposition to the government.

\section{Research on students' ideas}

Another challenge faced by Singapore teachers is the likelihood that students enter classrooms with a range of prior knowledge, understandings and experiences related to history. They may have strongly held views about particular episodes in history, and misconceptions that are difficult to address. In Afandi's (2012) study of 50 Singaporean secondary school (Year 9, 14-15 years old) students' ideas about historical accounts, he found that students held a range of preconceptions, which he categorized in three broad categories of ideas. One group of students ( 27 students, or 54 per cent) viewed historical accounts as factual or as copies of a fixed, objective past. Another group (12, or 24 per cent) expressed the idea that there were multiple versions of the past that represented historians' viewpoints. The third group (11, or 22 per cent) understood that historical accounts are based on the interpretative work of historians. Because accounts represented the work of historians trying to answer questions about the past, these students were more aware that they could critically evaluate the accounts using certain criteria and standards for scholarly work.

This factual-multiple-criterial progression of students' ideas mirrored (in slightly different ways) Project CHATA's (Concepts of History and Teaching Approaches) progression models, which indicated that UK students' ideas ranged from low-level, simplistic conceptions about historical accounts to more sophisticated ideas based on an understanding of history as a public form of knowledge (Lee and Ashby, 2000). These findings, and progressions of students' ideas about accounts, are consistent across contexts as diverse as Taiwan (Hsiao, 2008), South Korea (Park, 2008) and the UK (Chapman, 2009).

To elaborate on the ways students viewed accounts in Singapore, students who approached historical accounts as factual believed they were either correct or incorrect representations of the past. Tze Kiat provided a typical response in this category to questions about why there are different accounts or stories about the past, and how one might decide if one is better than another:

What makes the story true are the facts. Facts are fixed. They cannot be changed ... So, if it's factual, then it's true ... But sometimes, the historian is biased and puts in his own views, sometimes deliberately ... so when that happens ... then it's not true.

For students in this category, there could not be competing accounts since only one could be accurate or truthful. Other students, however, recognized that multiple accounts of the same bit of history were possible. These different accounts were attributed to the different perspectives of historians. As Zain explained:

As human beings, we all have different experiences, different feelings about the same thing, so we will definitely have different views, different perspectives on things... Because of this, there will always be different stories about Singapore's history ... because people will always have different views on certain decisions made or certain historical events that happened.

Students in this category decided which account was better by using two different strategies: (1) assembling a 'complete story' using parts of the different accounts 
provided; or (2) picking the most common account as a majority position, while ignoring those accounts that represented a minority position. While acknowledging multiple accounts, students in this category did not know how to adjudicate between competing or contradictory accounts.

Students in the third category tended to approach the issue of multiple accounts in a criterial manner. These students had greater awareness of the constructed nature of accounts - that accounts are authored by historians to answer their specific questions, and that this required using evidence from primary sources to construct explanations. For example, Lena attributed varied accounts to 'differences due to the objectives of the historian', and suggested that some historians may follow more rigorous methods and standards in constructing their account. Students such as Lena pointed to disciplinary standards for constructing accounts, and either explicitly or implicitly suggested these standards could be used to evaluate different accounts.

It is clear then that a significant percentage of Singaporean students can understand that accounts of the past may be different but valid through reading the accounts of historians. Therefore, Afandi (2012) concluded that for students to develop more sophisticated and powerful understandings of history, they must be taught how to think about the ways accounts are constructed and how they can be evaluated in criterial terms. He suggested that teachers need to understand the epistemic and methodological underpinnings of the discipline, as well as be responsive to the preconceptions and ideas students are likely to have about the past. Such an approach is outlined below.

\section{The case of Operation Coldstore: Implementing a disciplinary approach to historical controversy}

Coming to grips with the discipline of history requires understanding the methods and standards used to make valid claims about the past and build historical knowledge (Lee and Ashby, 2000). Developing such understandings requires engaging students with authentic historical problems and helping students develop the conceptual tools necessary to address these problems and organize their knowledge about the past.

Second-order concepts, such as the concepts of accounts, significance, evidence and causation, provide these intellectual tools. They also structure historical debates; they are absolutely vital for understanding 'how histories are put together and what counts as a valid historical argument' (Seixas and Morton, 2013: 3). To understand historical controversy, then, it is important that students especially develop understandings of accounts and evidence as they engage with competing or contradictory historical accounts.

Our approach focuses on helping teachers and students develop deeper awareness of the ways knowledge about the past is constructed, and the central role that historians play in that process. The lesson activities were developed within the Historian's Lab project, a signature programme of the Humanities and Social Studies Education Academic Group of Singapore's National Institute of Education. Designed with the help of professional historians, lesson activities offer participants opportunities to acquire initial understandings about the nature of historical knowledge and the processes embedded within historical enquiry. The aim is to help students develop a deeper awareness of the ways knowledge about the past is constructed, and the central role historians play in creating that knowledge. By engaging teachers and students in authentic historical problems and specially crafted intellectual tasks, participants are 
guided to understand the ways historians construct knowledge about the past, and through this process develop sound historical reasoning skills.

In this section, we describe the learning stages to help students understand how to deal with different accounts put forward by historians in Singapore about Operation Coldstore, a security operation in 1963 that led to the arrest of suspected communists. Historians disagree over whether the communist threat was real or a pretext for weakening opposition to the People's Action Party (the current ruling party in Singapore). The Operation Coldstore lesson was designed to be taught to O-level examination secondary students, aged 15 , but the topic is not an examinable one. The activities designed within the lesson package can nonetheless help students with their history examination assessment, which is in part a source-based study intended to develop their skills of evaluating the validity of sources to answer source-based questions.

Our approach codifies a version of historical practice as constituting five specific procedures (see Figure 1), and proposes a model of instructional strategy that can operationalize the suggested approach for the purpose of teaching and learning (see Figure 2).

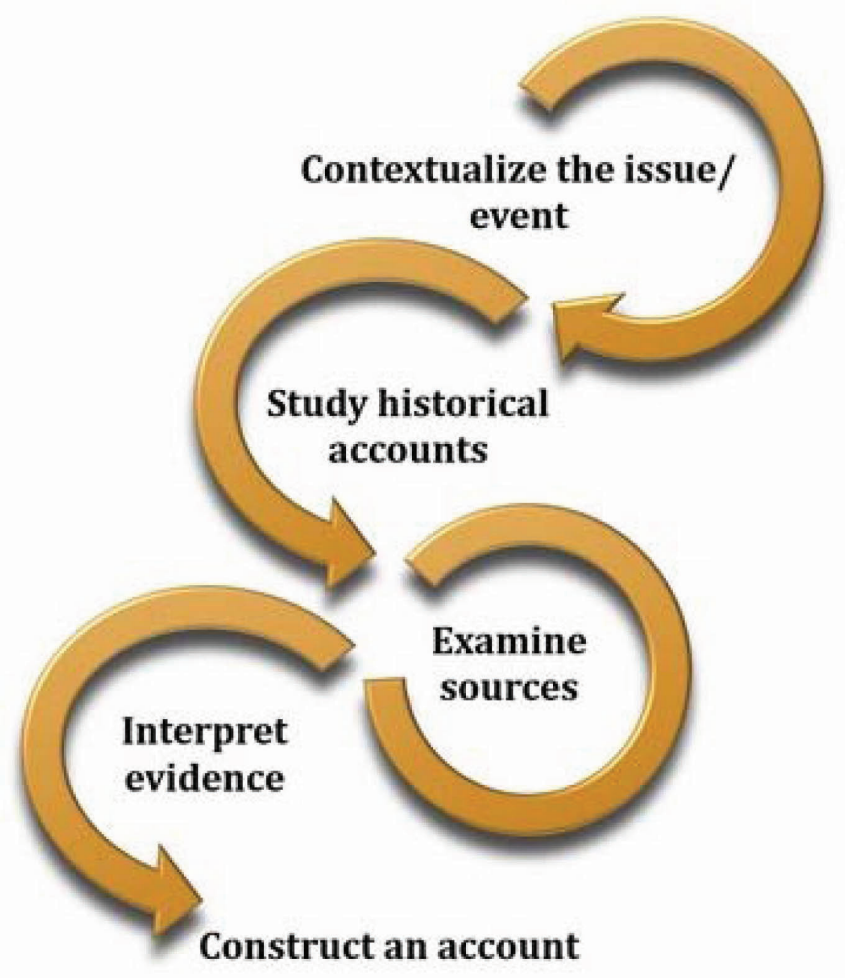

Figure 1: Approaching a historical study 


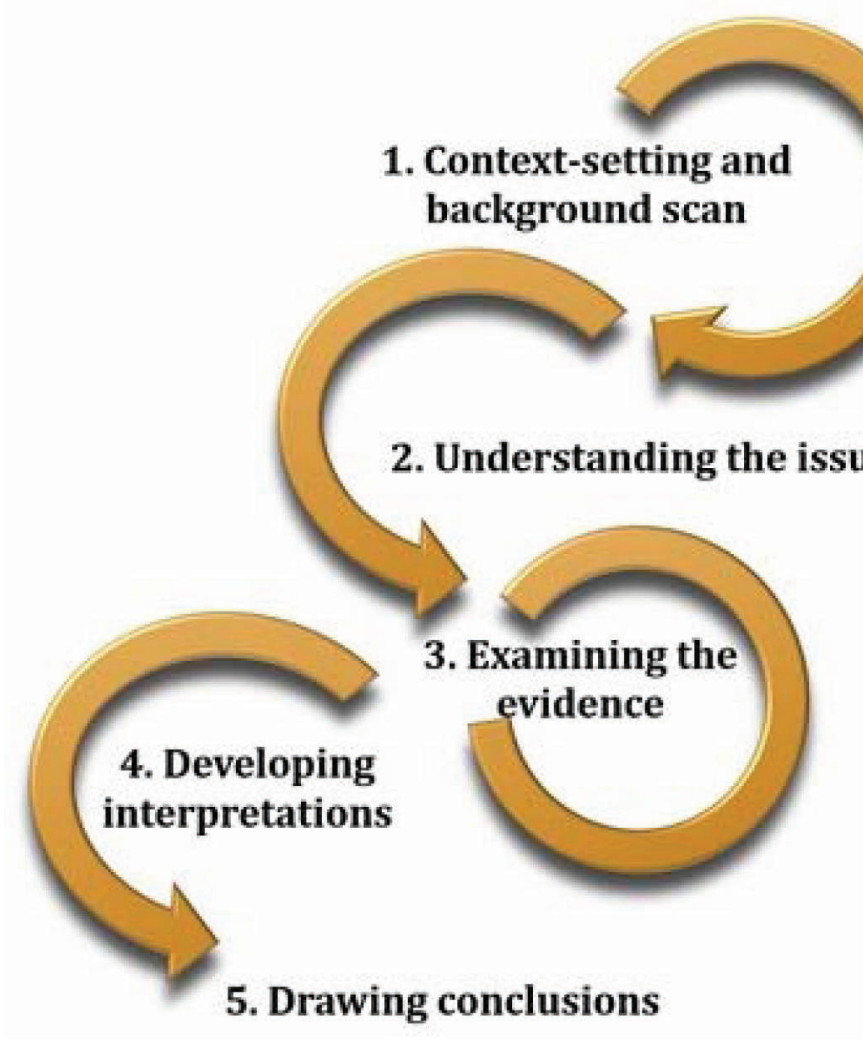

Figure 2: Instructional model

In line with an enquiry-based learning design and the focus on presenting authentic historical problems, the Operation Coldstore case of 1963 is used to demonstrate historical practice in action. This event was seen as one of several critical moments in Singapore's pre-independence history, and was contentious on two related counts: first, that the government's crackdown on alleged communist and leftist political leaders was viewed as politically motivated and as an expedient move by the governing People's Action Party (PAP) to suppress political opponents; and second, the view that the security threat posed by opposition party leaders (the Barisan Sosialis) was very much overstated, and that there was scant evidence to justify the mass arrests (Lim, 2015). In keeping with the spirit of the historical debate, the enquiry question for the learning module was framed as:

Was Operation Coldstore driven by a genuine security threat or was it politically motivated?

There are three key components to the learning module:

(1) the Learning Stages that demarcate the specific phases of learning exemplified by the approach in Figure 2

(2) Guiding Questions that accompany each learning stage and support discussion in tandem with the instructional strategy

(3) a Reflect and Deliberate segment, where participants are given time to reflect on and take stock of their learning experiences, while considering possible gaps in their knowledge that they wish to address.

The stage-based flow is shown in summarized form in Table 1, with explanatory notes for each of the stages. 
Table 1: Summary of learning stages, guiding questions and points for reflection

\begin{tabular}{|c|c|c|}
\hline Learning Stage & Guiding Questions & Reflect and Deliberate \\
\hline $\begin{array}{l}\text { STAGE 1: } \\
\text { Context-setting } \\
\text { and background } \\
\text { scan } \\
\text { (a) What was the } \\
\text { world like in the } \\
\text { 1960s? } \\
\text { (b) What do you } \\
\text { know about } \\
\text { Operation } \\
\text { Coldstore? }\end{array}$ & $\begin{array}{l}\text { (a) Open discussion: } \\
\text { What do you know about the 1960s? } \\
\text { What was the world like? What were } \\
\text { the global social, economic or political } \\
\text { forces at work? } \\
\text { (b) More specific discussion: } \\
\text { What was happening in Singapore in } \\
\text { the } 1960 \text { s? } \\
\text { What happened during Operation } \\
\text { Coldstore? When did it take place? } \\
\text { Who were involved? Why was it carried } \\
\text { out? How did it end? } \\
\text { What was the impact of Operation } \\
\text { Coldstore on local politics? }\end{array}$ & $\begin{array}{l}\text { Points for reflection: } \\
\text { How does knowing the } \\
\text { context shape your initial } \\
\text { understandings of the event? } \\
\text { Was Operation Coldstore } \\
\text { an isolated political event in } \\
\text { Singapore's history or should } \\
\text { it be seen as part of wider } \\
\text { political developments? } \\
\text { What other questions do you } \\
\text { have? }\end{array}$ \\
\hline
\end{tabular}

\section{Notes:}

This stage initiates the investigative process by drawing students' attention to important issues or events taking place internationally, while situating the event within the context of wider political developments of the time (for example, the Cold War). A key objective of this beginning learning stage is to offer students contextual familiarity that can allow them to orient themselves in place and time. Activities that can support learning outcomes during this stage include textbook accounts, infographics or video-clips that talk about the international situation in the 1960s, and pre-prepared summary write-ups about the event being studied (see Appendix 1, for example).

$\begin{array}{lll}\text { STAGE 2: } & \text { What have historians said about } & \text { Points for reflection: } \\ \text { Understanding } & \text { Operation Coldstore? What claims have } & \text { In what ways do these } \\ \text { the issue } & \text { they made? What arguments have they } & \text { accounts differ from one } \\ \text { What have } & \text { put forward? } & \text { another? } \\ \text { historians said } & \text { Looking at the two historians' extracts } & \text { Why do these historians } \\ \text { about the event? } & \text { provided, how would you say they differ } & \text { disagree? } \\ \text { (See Appendix } & \text { in terms of their approach to Operation } & \text { Whose argument seems more } \\ \text { 2: Examining } & \text { Coldstore? What are the points of } & \text { convincing to you (at this } \\ \text { historians' claims.) } & \text { agreement or disagreement? } & \text { point)? What would help you } \\ & & \text { in your decision? }\end{array}$
Notes:
In this stage, preliminary understanding of the event is developed further through exploring
historians' accounts and identifying authors' positions, claims and arguments. Students will be
introduced to the nature of historical writing, the claims that historians make about the past
and possible explanations for their disagreements. For this activity, students will be presented
with two historians' accounts (from opposing positions) and given guidance on examining
these accounts to locate standpoint, argument, claim and so on. Learning scaffolds (such as
the one provided in Appendix 2) will be useful to assist students in the task.

\begin{tabular}{|c|c|c|}
\hline $\begin{array}{l}\text { STAGE 3: } \\
\text { Examining the } \\
\text { evidence } \\
\text { What does the } \\
\text { analysis of primary } \\
\text { sources suggest? } \\
\text { (See Appendix 3: } \\
\text { Examining primary } \\
\text { sources.) }\end{array}$ & $\begin{array}{l}\text { From analysis of Source } 1 \text { and Source } 2 \\
\text { (by turn): } \\
\text { How credible or reliable is this source? } \\
\text { What does the evidence tell us? } \\
\text { Do other sources exist? What do other } \\
\text { pieces of evidence say? } \\
\text { Who was the intended audience for this } \\
\text { source? } \\
\text { Does knowing the origins of the source } \\
\text { influence your understanding of it? }\end{array}$ & $\begin{array}{l}\text { Points for reflection: } \\
\text { Did your careful analysis of } \\
\text { the primary sources support } \\
\text { or challenge what you know } \\
\text { about the event? } \\
\text { Were the claims made by the } \\
\text { two historians confirmed or } \\
\text { challenged by the available } \\
\text { evidence? }\end{array}$ \\
\hline
\end{tabular}




\begin{tabular}{|c|c|}
\hline Learning Stage & Reflect and Deliberate \\
\hline $\begin{array}{l}\text { Notes: } \\
\text { By this stage, stud } \\
\text { past. They should } \\
\text { analysis of primar } \\
\text { the instructional s } \\
\text { comprehend and } \\
\text { For this activity, st } \\
\text { support opposing } \\
\text { of relevance, relia } \\
\text { provided in Apper }\end{array}$ & $\begin{array}{l}\text { nts should be aware that historians use evidence to make claims about the } \\
\text { also recognize that logical arguments are evidence-based and require the } \\
\text { sources. By providing students with access to selected primary records, } \\
\text { rategy in this stage focuses on developing students' ability to examine, } \\
\text { valuate source materials in light of the claims made by the two historians. } \\
\text { idents will be presented with two primary sources (which may be used to } \\
\text { claims), and given guidance on examining these sources to identify issues } \\
\text { ility, purpose, provenance and so on. Learning scaffolds (such as the one } \\
\text { dix 3) will be useful to assist students in the task. }\end{array}$ \\
\hline
\end{tabular}

\begin{tabular}{|c|c|c|}
\hline $\begin{array}{l}\text { STAGE 4: } \\
\text { Developing } \\
\text { interpretations } \\
\text { How do you make } \\
\text { sense of the }\end{array}$ & $\begin{array}{l}\text { What can you interpret from the } \\
\text { evidence (in light of the question)? } \\
\text { What assertions can you make to } \\
\text { support your interpretation? } \\
\text { Are there other possible }\end{array}$ & $\begin{array}{l}\text { Will you attempt to reconcile } \\
\text { or synthesize existing } \\
\text { interpretations, or will you put } \\
\text { forward a new claim? }\end{array}$ \\
\hline
\end{tabular}

sense of the Are there other possible

evidence/issue interpretations?

thus far?

\begin{abstract}
Notes:
At this stage, students should have a reasonable understanding of some of the key issues involved, and have reviewed the evidence historians have used to support or challenge the contention, that is, whether Operation Coldstore was a genuine security threat or if the event was politically motivated. Opportunities will be provided for them to evaluate and assess the claims put forward, and for them to develop their respective interpretations. Through active guidance, students may choose to reconcile or synthesize the different claims/interpretations. They may also be encouraged to develop interpretations that may not conform to an 'either/ or' position as exemplified by the debate.
\end{abstract}

$\begin{array}{ll}\text { STAGE 5: } & \text { Your conclusion: } \\ \text { Drawing } & \text { Operation Coldstore was essentially ... } \\ \text { conclusions } & \\ \text { Based on } & \\ \text { what you have } & \\ \text { gathered, what } & \\ \text { conclusion can } & \\ \text { you make in light } & \\ \text { of the question? } & \end{array}$

Notes:
This final stage offers students the opportunity to synthesize, consolidate and demonstrate their
knowledge through the construction of an end product (as evidence of new understanding).
This can be done in the form of an extended writing exercise that requires them to put forward
their own conclusions in light of the enquiry question. Students should be reminded that
their end product, as a piece of writing, is subjected to the standards, norms and rigour of
academic writing. In this regard, they would do well to consider the strength of their argument,
the evidence used to support their claims, and the validity of their conclusions. Appendix 4
may be useful in providing students with some important considerations when formulating
their conclusions.

Approaching the study of the past through processes and procedures governing the historical discipline allows students to develop deeper familiarity with the nature of historical knowledge. They can learn about the kind of work that historians do, and understand how historians interpret and use evidence to support the claims they make about past events. The recognition that historical knowledge is constructed and rests upon disciplined interpretation of evidence will allow students to view historical accounts (and the interpretations they carry) as tentative and open to challenge. An approach 
that encourages students to grapple with multiple or competing interpretations of the past is more likely to strengthen students' awareness of the tentative nature of historical knowledge, and the ways historians endeavour to interpret and understand the complex human past. As participants are guided through the activities in each of the five phases, they are encouraged to think like historians engaging in historical study. Disciplinary competencies, such as interrogating primary sources, interpreting evidence and arbitrating between historical claims, are developed in the process. While students' historical understanding is likely to develop over time, this approach offers opportunities to ensure that there is adequate space to develop such understandings within the curriculum.

\section{Beginning to think like historians}

Based on students' work during the lesson, a few elements can be put forward that show students' initial ideas about competing historical accounts. Students demonstrated an ability to understand that there were different perspectives surrounding the issue. When asked to develop their own interpretations and conclusions at the end of the lesson (Stages 4 and 5), most students felt that both accounts were 'equally' convincing, and thus stated that Operation Coldstore was politically motivated as well as a genuine security threat. Most students attempted to present a balanced view of the issue based on the competing accounts provided by the historians and the two primary sources they examined. Lidia, for instance, stated that:

Because communism was spreading and causing trouble in the country, the PAP [People's Action Party] wanted to cement its grip for power by getting rid of the communists. PAP wanted to govern Singapore so that there would not be opposition that would disagree with PAP. Hence, PAP had some intention of suppressing the opposition and [gaining] their political foothold.

Her interpretation is an attempt to reconcile the two opposing views of the issue by saying that communism could be a potential threat to the formation of the nation, but that eliminating opposition would also solidify PAP rule. Some students, such as Sam, attempted to contextualize the issue:

Before PAP's governance, Singapore was ruled by the British and thus PAP could have been influenced by the British that communism is a threat to the world. PAP could then use this threat to influence Singaporeans and gain power over the Communist Party.

These responses indicate some aspects of historical reasoning in which students are developing their own conclusions based on considering contextual factors as well as available evidence.

Three students insisted on the need to 'acquire more sources to conclude the main intention of Operation Coldstore'. One student noted greater motivation by stating that the lesson had intrigued him, and that he would like to conduct more research on the matter. However, some students had difficulty reconciling the different accounts to build their own conclusions about the issue. For example, one of the students stated that:

... it was hard trying to come to a conclusion as a lot of the sources contradict one another, while still making sense in their own way. This 
made it hard for me to be able to come to a more reasonable conclusion about the matter.

Similar to Afandi's (2012) study, students demonstrated a range of ideas about the historical accounts used in the activity. For students to develop more sophisticated and powerful understandings of history, they need more experience and guided practice in thinking about historical accounts and how they can be evaluated. This lesson, and the forms of scaffolding provided, represents a first step in helping students come to grips with a complex past and the nature of historical accounts.

Finally, it is interesting to consider the teachers' perspectives on the changes they identified in their students' approach to the discipline. For the two teachers who taught Operation Coldstore to their students, they believed this enquiry-based approach helped students understand better the meaning and relevance of history as a discipline, and increased student engagement in the learning of history through 'doing' and 'experiencing', as opposed to didactic modes of history teaching. They indicated that they saw this approach as leading to deeper enquiry into subject matter, and that it also helped students to connect their learning in the classroom to the work of historians.

\section{Implications and conclusion}

The notion that history education is just the linear transmission of knowledge has long run out of currency. Studies have shown that the transmission approach to teaching - that is, the transferring of a single narrative of historical events from teacher to student - yields low-quality, surface-level learning outcomes (Trigwell et al., 1999). Rather, the utility of the disciplinary approach to help students understand and draw upon disciplinary methods, concepts and standards of practice supports powerful knowledge building in history. In practice, the history teacher acts as a facilitator to engage and direct students towards arriving at conceptual understanding of their own accord. The approach to teaching historical controversy that we have presented in this article embodies this practice in its essence.

The teacher elicits students' preconceptions of historical events prior to addressing any misconceptions by way of introducing different accounts and explanations. Students are then encouraged to consider the various accounts and critically evaluate them using disciplinary criteria. In the last stage, students are stimulated to consolidate and synthesize their knowledge in order to arrive at a new historical understanding that was not previously held. At every stage of this approach, the students are the focal point of classroom activity, rather than the teacher. In using this approach, students are not only able to develop their critical thinking skills, but are also transformed into active, independent learners in the process.

Such a pedagogical method is not new to history education. Placing genuine historical controversy within a framework of historical interpretation has been a feature of history education in the UK, and the benefits of teaching controversial issues is well-established in international scholarship (Barton and McCully, 2007). However, teaching controversial topics can still be challenging for teachers, and often depends on national, community and school contexts. This has especially been the case in some Asian contexts, such as Singapore, that have traditions of social deference to authority and histories of political authoritarianism (Loh et al., 2013). A disciplinary approach to historical controversy is one way to manage these challenges.

In order to promote a more powerful history education in schools, history curriculum planners would be well-advised to include controversial history topics 
in the curriculum. Controversies offer multiple viewpoints and accounts, which require the learner to exercise his or her critical thought and reasoning skills in order to make informed judgements about the past. When students are exposed to contested accounts of a particular historical event, they get first-hand experience of the complexities involved in the construction of historical knowledge. Through the disciplinary approach to teaching historical controversy that we have outlined, students will come to an understanding of how historians construct different interpretations of a single historical event, and they will have opportunities to critically arbitrate and adjudicate such different interpretations and accounts.

Sensitizing students to multiple competing accounts through the teaching of controversy has become particularly necessary in a 'post-truth' age. The twenty-first century, through rapid technological innovation, has seen an exponential increase in information online and, more recently, the emergence of popularized terms such as 'alternative facts' and 'fake news'. Students are now not only gaining information and knowledge outside the classroom, but are also becoming aware of alternative accounts of past and current events. They may be easily swayed by fake news and conspiracy theories that lack substantive content. Even the Singapore government, in its 'battle against fake news', has maintained that education is integral to developing discerning information users and 'a society that can pick up and understand what is fake' (Seow, 2017). We believe that teaching controversy in classrooms would form the foundations for such a society.

\section{Notes on the contributors}

Mark Baildon is Associate Professor and Head of Humanities and Social Studies Education at the National Institute of Education, Nanyang Technological University, Singapore. He has taught social studies in the United States, Israel, Singapore, Saudi Arabia and Taiwan. He has authored Social Studies as New Literacies in Global Society: Rational cosmopolitanism in the classroom (with James Damico) (Routledge, 2011) and co-edited Controversial History Education in Asian Contexts (Routledge, 2013).

Suhaimi Afandi is Senior Lecturer in Humanities and Social Studies Education at the National Institute of Education, Nanyang Technological University, Singapore. He received his doctoral degree from the UCL Institute of Education. His research interests centre on students' ideas about history and how knowledge about the past is received and understood. He also focuses on development work, building students' disciplinary understandings through greater exposure to the historian's craft.

Sandra Bott is a lecturer at the University of Lausanne, Switzerland. She was a Research Associate with the Humanities and Social Studies Education Academic Group, National Institute of Education, Nanyang Technological University in Singapore, where she worked on two projects on global citizenship and history education. She holds a PhD in history from the University of Lausanne, where she has conducted research on the political and economic role of neutrals in the Cold War.

Chelva Rajah is Senior Teaching Fellow at the Humanities and Social Studies Education Academic Group, National Institute of Education, Nanyang Technological University, Singapore. He has been seconded from the Ministry of Education since 2010 as a history educator, and teaches pre-service, in-service and postgraduate courses in history. He has 23 years' experience teaching history and social studies in schools. 


\section{References}

Afandi, S.M. (2012) 'Conceptions about the Nature of Accounts in History: An exploratory study of students' ideas and teachers' assumptions about students' understandings in Singapore'. Unpublished PhD thesis, Institute of Education, University of London.

Afandi, S. and Baildon, M. (2010) 'History education in Singapore'. In Nakou, I. and Barca, I. (eds) Contemporary Public Debates over History Education (International Review of History Education 6). Charlotte, NC: Information Age Publishing, 223-42.

Afandi, S. and Baildon, M. (2015) 'Anxieties over Singapore students' conceptions about history and the past'. HSSE Online, 4 (2), 36-47. Online. www.hsseonline.edu.sg/sites/default/files/uploaded/ journal_articles/suhaimimark.pdf (accessed 26 June 2018).

Baildon, M. and Afandi, S. (2014) 'A disciplinary approach to teaching historical controversy in Singapore's schools: The case of the Internal Security Act'. In Baildon, M., Loh, K. S., Lim, I.M., Inanç, G. and Jaffar, J. (eds) Controversial History Education in Asian Contexts. London: Routledge, 196-217.

Baildon, M. and Afandi, S. (2017) 'The myth that a singular narrative moulds good citizens'. In Loh, K.S., Thum, P.J. and Chia, J. (eds) Living with Myths in Singapore. Singapore: Ethos Books, 29-39.

Baildon, M.C. and Sim, J.B.-Y. (2009) 'Notions of criticality: Singaporean teachers' perspectives of critical thinking in social studies'. Cambridge Journal of Education, 39 (4), 407-22.

Barton, K. and McCully, A. (2007) 'Teaching controversial issues... where controversial issues really matter'. Teaching History, 127, 13-19.

Chapman, A.J. (2009) 'Towards an Interpretations Heuristic: A case study exploration of 16-19 year old students' ideas about explaining variations in historical accounts'. Unpublished EdD thesis, Institute of Education, University of London.

Chapman, A. (2011) 'Historical interpretations'. In Davies, I. (ed.) Debates in History Teaching. London: Routledge, 96-108.

Deng, Z. and Gopinathan, S. (2016) 'PISA and high-performing education systems: Explaining Singapore's education success'. Comparative Education, 52 (4), 449-72.

Foster, S. (2014) 'Teaching controversial issues in the classroom: The exciting potential of disciplinary history'. In Baildon, M., Loh, K.S., Lim, I.M., İnanç, G. and Jaffar, J. (eds) Controversial History Education in Asian Contexts. London: Routledge, 19-38.

Foster, S. and Crawford, K. (2006) 'Introduction: The critical importance of history textbook research'. In Foster, S.J. and Crawford, K.A. (eds) What Shall We Tell the Children? International perspectives on school history textbooks. Greenwich, CT: Information Age Publishing, 1-23.

Gopinathan, S. (1999) 'Preparing for leadership in education: The Singapore experience'. Paper presented at the Fourth Conference of the International Confederation of Principals, Helsinki, 14 July.

Hogan, D., Chan, M., Rahim, R., Kwek, D., Aye, K.M., Loo, S.C., Sheng, Y.Z. and Luo, W. (2013) 'Assessment and the logic of instructional practice in Secondary 3 English and mathematics classrooms in Singapore'. Review of Education, 1 (1), 57-106.

Hsiao, Y.-M. (2008) 'Taiwanese Students' Ideas about Historical Accounts with Special Reference to Their Perceptions of History Textbooks'. Unpublished PhD thesis, Institute of Education, University of London.

Körber, A. (2015) Historical Consciousness, Historical Competencies - and Beyond? Some conceptual development within German history didactics. Frankfurt am Main: Deutsches Institut für Internationale Pädagogische Forschung. Online. www.pedocs.de/volltexte/2015/10811/pdf/ Koerber_2015_Development_German_History_Didactics.pdf (accessed 26 June 2018).

Lee, H.L. (1997) 'The launch of National Education'. 17 May. Online. www.nas.gov.sg/archivesonline/ speeches/view-html?filename=1997051607.htm (accessed 14 July 2018).

Lee, P.J. (1991) 'Historical knowledge and the national curriculum'. In Aldrich, R. (ed.) History in the National Curriculum. London: Kogan Page, 39-65.

Lee, P. (2011) 'History education and historical literacy'. In Davies, I. (ed.) Debates in History Teaching. London: Routledge, 63-72.

Lee, P. and Ashby, R. (2000) 'Progression in historical understanding among students ages 7-14'. In Stearns, P.N., Seixas, P. and Wineburg, S. (eds) Knowing, Teaching and Learning History: National and international perspectives. New York: New York University Press, 199-222.

Lim, Y.L. (2015) 'Revisiting Operation Coldstore'. Straits Times, 13 April. Online. www.straitstimes. com/opinion/revisiting-operation-coldstore (accessed 26 June 2018).

Loh, K.S., Baildon, M., Lim, I.M., İnanç, G. and Jaffar, J. (2014) 'Introduction: Controversy, history and history education in Asia'. In Baildon, M., Loh, K.S., Lim, I.M., Inanç, G. and Jaffar, J. (eds) Controversial History Education in Asian Contexts. London: Routledge, 3-18. 
Nordgren, K. (2016) 'How to do things with history: Use of history as a link between historical consciousness and historical culture'. Theory and Research in Social Education, 44 (4), 479-504.

Park, J. (2008) 'Students' Ideas about Different Representations of the Past: South Korean adolescents interpret historical film'. Unpublished PhD thesis, Institute of Education, University of London.

Seixas, P. and Morton, T. (2013) The Big Six Historical Thinking Concepts. Toronto: Nelson Education.

Seow, B.Y. (2017) 'Shanmugam sets out strategies in battle against fake news'. Straits Times, 20 June. Online. www.straitstimes.com/singapore/shanmugam-sets-out-strategies-in-battleagainst-fake-news (accessed 26 June 2018).

Trigwell, K., Prosser, M. and Waterhouse, F. (1999) 'Relations between teachers' approaches to teaching and students' approaches to learning'. Higher Education, 37 (1), 57-70. 


\section{Appendix 1: Summary of Operation Coldstore}

INVESTIGATING OPERATION COLDSTORE: GENUINE SECURITY THREAT OR POLITICALLY MOTIVATED?
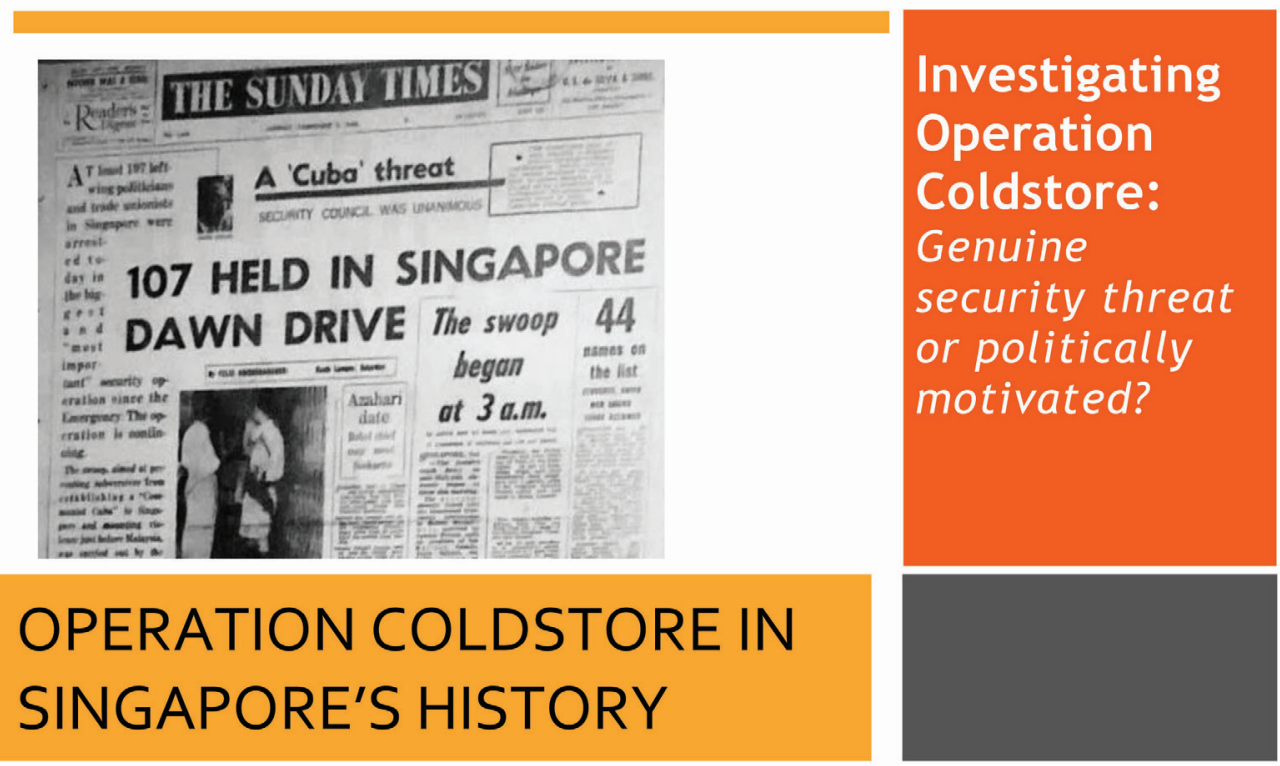

\section{Background}

In 1959, the People's Action Party (PAP) was elected as the government to bring Singapore forward on the road of selfgovernment. Under the terms of the agreement negotiated with the British in 1957, the elected Singapore government and Legislative Assembly would be responsible for all matters except foreign affairs, military defence and internal security.

By February 1963, the PAP government led by then-Prime Minister Lee Kuan Yew had negotiated a possible framework of merger between Singapore and Malaya. Disputes over the terms and conditions of merger between PAP and the other opposition parties led to a referendum in September 1962 with the majority of people voting for PAP's merger proposals.

\section{The Basic Facts}

What was it? A security operation launched by the underground network throughout the Internal Security Council in Singapore island. Those who escaped the police net that was touted as an anti-communist went into hiding." (Chin Peng, Alias Chin operation.

When did it take place? Peng: My Side of History, 439).

Impact of Operation Coldstore

Operation Coldstore took place on 2 The arrests under Operation Coldstore February 1963 beginning with a mass removed from the political scene the arrest of more than a hundred left-wing leaders of Barisan Socialis, then the major political, trade union and student leaders opposition party in the Legislative opposed to the formation of Malaysia. Assembly and paved the way for the PAP

Who were affected? government to push through merger plans with Malaya. It has been seen as a Many of those arrested included Lim Chin key turning point in the political history of Siong, half of the Barisan Socialis' (lit. Singapore and yet one that is, until Socialist Front) central executive recently, very much unknown and uncommittee and sympathisers close to the researched. Recent research by academic party, such as journalist Said Zahari. Most historians and personal recollections of them would go on to spend many years from former detainees have sought to in detention without trial. Their arrests rebut the official account, thus evoking a sparked off protest riots which in turn led debate and controversy over Operation to further arrests. The political party Coldstore. 


\title{
Appendix 2: Focus: Examining historians' claims about Operation Coldstore
}

\author{
Question: Was Operation Coldstore driven by a genuine security threat or was it \\ politically motivated?
}

\section{Scaffold Example 1}

Source A: Loh Kah Seng, historian, in New Mandala (15 January 2015)

\begin{abstract}
Operation Coldstore was a massive police action jointly organised by the British, Singapore and Malayan governments on 2 February 1963, which detained over a hundred, mostly left-wing leaders on charges of conspiracy to establish a communist state in Singapore. Coldstore was a defining moment in Singapore's history - the arrests were an important pre-condition in the secret negotiations between the governments of Singapore, Malaya and Britain for the formation of Malaysia. The purge fatally weakened the left, which provided the main political opposition to the People's Action Party (PAP) government under Prime Minister Lee Kuan Yew, and paved the way for the establishment of a one-party state. Over the last decade, Coldstore has emerged as a public controversy. Former leftists have used newly declassified British archival records to openly reject the conspiracy charges and assert their role in the decolonisation of Singapore ... British sources demonstrate that Barisan Sosialis had pursued a constitutional struggle, that there was no case for the arrests, and that Britain had bowed to political pressure in conducting a security operation where no threat existed.
\end{abstract}

\begin{tabular}{|l|l|}
\hline $\begin{array}{l}\text { What claims are being } \\
\text { made in this account? }\end{array}$ & \\
\hline $\begin{array}{l}\text { What is the author's view } \\
\text { regarding Operation } \\
\text { Coldstore? }\end{array}$ & \\
\hline $\begin{array}{l}\text { Identify a claim the } \\
\text { author makes and } \\
\text { produce an argument he/ } \\
\text { she uses to support the } \\
\text { claim. }\end{array}$ & \\
\hline $\begin{array}{l}\text { Is there a limitation to } \\
\text { this claim/argument? }\end{array}$ & \\
\hline $\begin{array}{l}\text { Can you provide a } \\
\text { counterargument to } \\
\text { challenge the author's } \\
\text { claim? }\end{array}$ & \\
\hline
\end{tabular}

\section{Scaffold Example 2}

Source B: Kumar Ramakrishna, historian, in ipscommons.sg (19 February 2014)

History records that Coldstore was mounted to contain the threat to Singapore's security posed by the Communist United Front, then dominating key interest groups. P.J. Thum, a young Singapore historian, disputes this and argues instead that Coldstore represented a blatantly 
political exercise to destroy the legitimate 'progressive left wing' opposition that offered the only credible electoral challenge to Lee Kuan Yew's PAP ... Operation Coldstore must be seen in context - it occurred during a difficult episode in our history amidst a genuinely dangerous period in the Cold War, as evidenced by the Cuban Missile Crisis in Oct 1962, ongoing advances made by communists in Indochina, the Brunei revolt in Dec 1962, and of course the Indonesian Konfrontasi in Jan 1963. The revisionist view that Coldstore was utterly driven by Lee's obsession with political power is misleading. A more nuanced analysis suggests that reality at the time was defined by morally complex shades of grey. Ultimately, the moral test of tough policy choices must be whether they benefit a nation in the long run. Fifty-one years on, even critics concede that Singapore has blossomed into a cosmopolitan, politically stable and economically vibrant metropolis. History would therefore - on balance very likely adjudge that Coldstore passed this test.

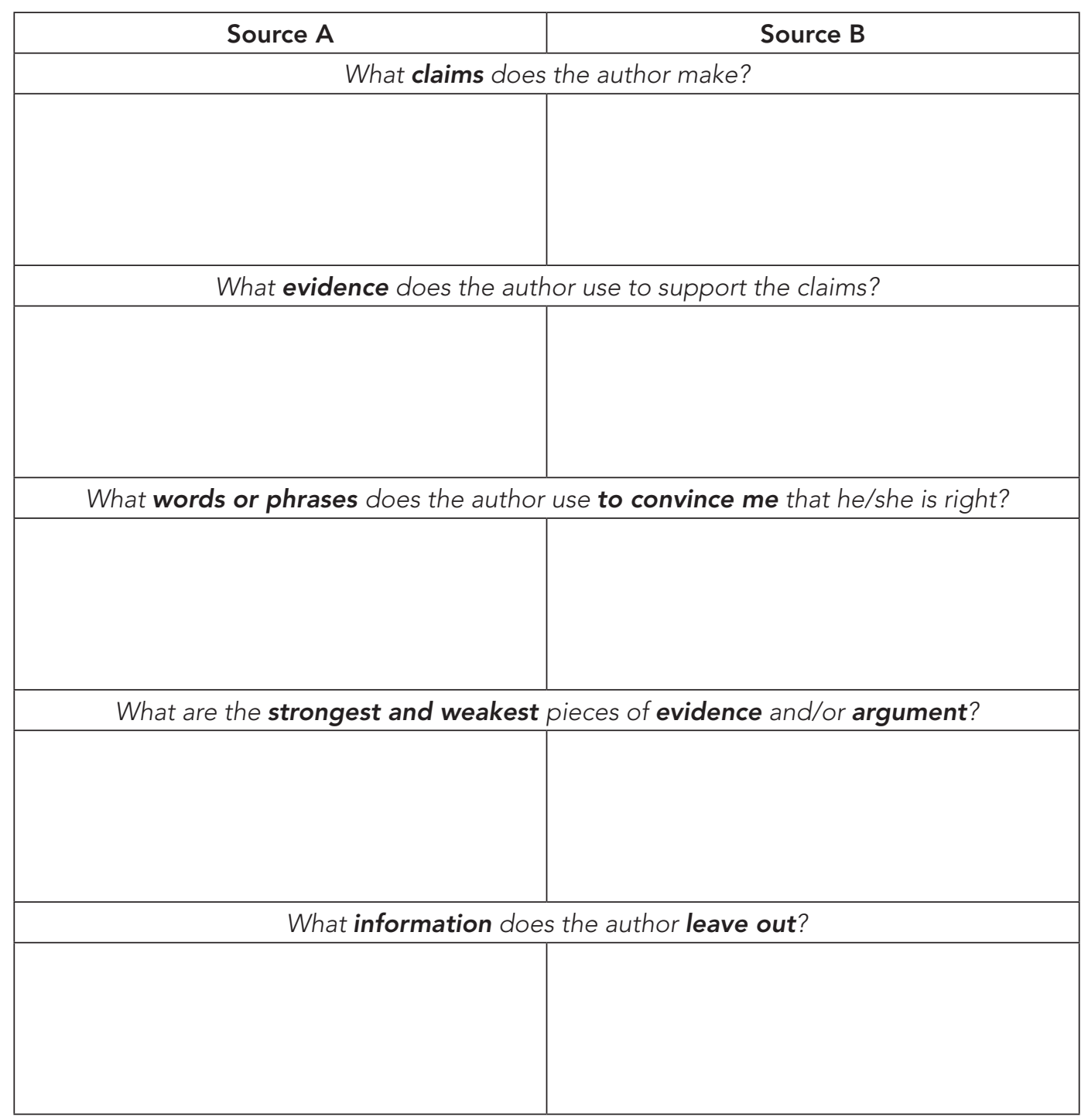




\section{Appendix 3: Examining primary sources}

\section{Question: Was Operation Coldstore driven by a genuine security threat or was it politically motivated?}

Source A: Poh Soo Kai, 'Singapore's "Battle for Merger" revisited', New Mandala, 3 December 2014

Except for the 1990s, the ISA [Internal Security Act] has been used in every decade in postwar Singapore. Operation Coldstore remains the most controversial, as it paved the way for the PAP's unbroken rule and constitutes its founding myth of 'riding the communist tiger'. What it did, in effect, was to eliminate Lim Chin Siong and the Barisan Sosialis from the 1963 general election. Lim had won the confidence not only of the Chinese-speaking labour unionists, but also the English-speaking left, mostly coming out from the University Socialist Club. I was one of them ... Documentary evidence from the colonial archives ... has shown that the British and the Federation governments were not going to accept a leftwing government in Singapore; they came to Lee's rescue by abetting in Operation Coldstore.

Source B: CO 1030/1160, Selkirk to SSC, Telegram No. 582, 14 December 1962

Lee Kuan Yew said he agreed with Ismail that action must now be taken. The perfect opportunity had been presented by the Brunei revolt and this must not be missed ... I said I had recognised all along that a threat was presented by the communists in Singapore. I had not however previously been convinced that a large number of arrests was necessary to counter this threat. Recently, however, new evidence had been produced about the extent of the communist control of the Barisan Sosialis and also there had been indications that the communists might resort to violence if the opportunity occurred. Recent statements by the Barisan Sosialis and Party Rakyat supporting the revolt in Brunei confirmed this. Accordingly, H.M.G. [Her Majesty's Government] were prepared to see action taken in Singapore ...

\section{Some possible ways to help students interrogate the sources}

\section{Consider source content:}

What is the author actually saying?

What is not written?

What can you say about the tone of

the source?

What words or phrases does the

author use to convince me that he/

she is right? 


\section{Consider source reliability:}

Is the author a credible source?

Are there reasons to doubt the

reliability of the source? Does

knowing the origins of the source

influence your understanding of it?

Can the claims be confirmed?

Are there other sources to back the

claims the author made?

Consider the usefulness of the source:

What can you learn from this source? Does it support what you

know about this event?

What is the worth of the source as useful evidence?

\section{Consider purpose:}

How does this document make me feel? Who was the intended audience for this source?

What are his/her possible

motivations for writing this? Does

the author have 'an axe to grind'?

Does he/she have any vested

interests?

Were the claims made by the two historians confirmed or challenged by the available evidence? 


\section{Appendix 4: Developing conclusions}

Was Operation Coldstore driven by a genuine security threat or was it politically motivated?

\begin{tabular}{|l|l|}
\hline $\begin{array}{l}\text { What is my interpretation } \\
\text { regarding Operation Coldstore, } \\
\text { and what conclusions can I draw? }\end{array}$ & \\
\hline $\begin{array}{l}\text { What can or have I selected to } \\
\text { support my claims/conclusions? }\end{array}$ & \\
\hline $\begin{array}{l}\text { Can the claims that I make be } \\
\text { confirmed? }\end{array}$ & \\
\hline $\begin{array}{l}\text { What are my strongest and } \\
\text { weakest pieces of evidence? }\end{array}$ & \\
\hline $\begin{array}{l}\text { How will I organize and integrate } \\
\text { my evidence? }\end{array}$ & \\
\hline $\begin{array}{l}\text { What other possible } \\
\text { interpretations or conclusions } \\
\text { should I be aware of? }\end{array}$ & $\begin{array}{l}\text { This is how my conclusion will look: } \\
\text { Operation Coldstore was essentially ... }\end{array}$ \\
\hline
\end{tabular}

